tinue to remain unresolved, as, for example, whether pinocytosis occurs in plant cells, or whether plastids or mitochondria arise from pre-existing organelles or from evaginations of the nuclear envelope. The preoccupation of the authors with root development is reflected in the frequent choice of EM photos of root cells of Zea to illustrate points, a matter which will draw criticism from some readers but appreciation from others. But the authors are not narrow. They draw on a wide range of information from plant and animal cell biology and make the appropriate contrasts and comparisons between plant and animal cells. As is to be expected, the nucleus receives considerable attention, as do chromosomes, but the emphasis is on cell structure and function rather than cytogenetical considerations.

There are some debatable interpretations and some omissions. Thus, for example, the first classic paper on freeze-etching by Steere is missing completely, and the intriguing research of Matile on isolated vacuoles from corn roots goes unmentioned. The interpretation of spindle fibres in terms of microtubular arrays is not clear; this view is offered as a possibility in one place (page 120) and then discarded elsewhere (page 220). While centrioles in animal cells get a brief mention, no attention is paid to their occurrence in lower plant cells, although the possibility that they may be found in plant cells generally is not ruled out. But these faults are minor. The book is well produced and the figures are of high quality. A carefully prepared glossary, an extensive bibliography, and an adequate index make information readily accessible and the volume particularly useful as a text. The book may well lead to the development of a new kind of course in plant cell biology at the university level. JoHN G. TORREY

\section{HARMFUL WORMS}

\section{Plant-Parasitic Nematodes}

Vol. 1. By A. A. Paramonov. Edited by K. Skrjabin. Translated from the Russian. Pp. v+390. (Israel Program for Scientific Translations: Jerusalem. Distributed in the UK by H. A. Humphrey, London, March 1969.) $160 s$.

The study of plant nematodes in the Soviet Union received its first real impetus in 1934 when I. N. Filipjev published his book on Harmful and Beneficial Nematodes in Agriculture. After his mysterious disappearance in 1937 while he was halfway through an English translation, the subject languished and interest did not quicken until 1952. Since then, A. A. Paramonov has played a leading part in the rapid development of plant nematology in Russia. The first volume of his book on Plant Parasitic Nematodes appeared in 1962, the second in 1964 and the third is yet to come. Few nematologists in Western countries read Russian, so that the translation of volume one is most welcome. Together with translations of the later volumes which will doubtless follow, it will make freely available an epitome of Russian research on plant nematodes and its underlying philosophy.

The first chapter deals with the relationships between nematodes and other Aschelminthes, relates them closely to Gastrotrichia, and postulates a common ancestry from primitive Turbellaria. The second chapter is devoted to factors in the interstitial environments of benthic debris, sand and soil that led to loss of cilia and the development of the cutaneomuscular sac, body turgor, serpentine movement and the other features characteristic of nematodes. The next three chapters describe detailed morphology, chapter six deals with embryology, development and life cycles, and chapter seven discusses ecological groupings. Chapters eight and nine deal with classification down to sub-families.

The text of volume one was written about ten years ago and so inevitably parts were already out of date when translated. Throughout, Paramonov stresses "concepts of ecological morphology", which leads to interesting speculations on relationships between form and function. In the discussions of morphology and physiology there is much uncertain ground because many nematode structures are near the limit of resolution of light microscopes and many more critical observations and experiments are needed on feeding, digestion, excretion and osmoregulation. One assertion that seems untenable is that feeding in the stylet bearing Tylenchida depends entirely on capillarity, which eliminates the need for muscular effort.

Paramonov thinks it essential to study the complex of nematodes that live around roots and within plants as a group if the diseases they cause are to be understood and rational control measures are to be formulated. This has led Russian nematologists to devote much time to saprobic nematodes some of which are said to injure plant tissues as do insects with biting mouthparts. To clarify the relationships between nematodes, plants and soil, Paramonov coins many technical terms. For example, eusaprobes inhabit foci of infection within plants and expand them, whereas dyssaprobes can feed on saprobic media but are also able to colonize healthy plants; and the stem nematode Ditylenchus dipsaci is dubbed an obligate anbiohelminth because it is able to live indefinitely in plant tissue and returns to the soil as a "survival habitat" only when the plant dies or is exhausted by overpopulation.

In his preface, the author says plant helminthology ought to adopt a system based on dialectical materialism. Evidently this does not include the virtue of brevity. Reading the long-winded, discursive style was a tiresome chore, and I could not help feeling that a ruthless editor would have improved the book immeasurably by cutting it drastically. However hard I tried, some passages remained obscure, which may be the fault of the transla. tion or of the original. There is no index and the list of contents is too brief to be helpful. The bibliography contains a useful list of papers by Russian authors.

F. G. W. JoNES

\section{COMPARATIVE ENDOCRINOLOGY}

\section{Perspectives in Endocrinology}

Hormones in the Lives of Lower Vertebrates. Edited by E. J. W. Barrington and C. Barker Jørgensen. Pp. xvi+ 583. (Academic Press: London and New York, December 1968.) $1408 ; \$ 22.50$.

THE book comprises eight chapters each about a selected topic in the endocrinology of lower vertebrates. In the first chapter, Barrington (Nottingham) makes a broad and thoughtful examination of the problems which beset any consideration of the evolution of the chordates. $\mathrm{He}$ emphasizes the dangers of using biochemical and physiological organization uncritically in order to propose phylogenetic arguments and he suggests the types of questions that must be answered. He then sets out, in the context of his approach, salient points in the contributions of the other seven authors. In the second, and longest chapter, Maetz (Villefranche-sur-mer) examines the modes of regulation of the movement of water and ions by biological tissues. $\mathrm{He}$ starts by presenting the basic physico-chemical laws involved and he then proceeds, in a masterly fashion, to show them at work together with the action of hormones on the biological tissues of lower vertebrates, chiefly teleost fish and amphibians. The next two chapters deal with the patterns of gonadal activity, the third by Barr (Buenos Aires) on the ovary and the fourth by Lofts (Hong Kong) on the testis. Both contributions are comprehensive and authoritative and that on the testis is particularly well illustrated. In the next 